\title{
Epidermal growth factor receptor and K-RAS mutations in 411 lung adenocarcinoma: A population-based prospective study
}

\author{
LAURA BOLDRINI ${ }^{1}$, GRETA ALİ ${ }^{1}$, SILVIA GISFREDI ${ }^{1}$, SILVIA URSINO ${ }^{1}$, EDITTA BALDINI ${ }^{2}$, \\ FRANCA MELFI $^{3}$, MARCO LUCCHI $^{3}$, CAMILLA E. COMIN $^{4}$, CRISTINA MADDAU $^{5}$, CARMELO TIBALDI $^{6}$, \\ TIZIANO CAMACCI ${ }^{1}$, ADELE SERVADIO $^{1}$, ALFREDO MUSSI $^{3}$ and GABRIELLA FONTANINI ${ }^{1}$
}

\begin{abstract}
${ }^{1}$ Department of Surgery, University of Pisa, ${ }^{2}$ Medical Oncology-Oncology Department S. Chiara, University Hospital Pisa, ${ }^{3}$ Department of Cardio-Thoracic Surgery, University of Pisa, 56100 Pisa; ${ }^{4}$ Department of Human Pathology and Oncology, University of Florence; ${ }^{5}$ U.O. Citopatologia CSPO Florence; ${ }^{6}$ Medical Oncology, Civil Hospital, Livorno, Italy
\end{abstract}

Received February 9, 2009; Accepted March 30, 2009

\section{DOI: 10.3892/or_00000488}

\begin{abstract}
Targeting the epidermal growth factor receptor has played a central role in advanced non-small cell lung cancer research, treatment, and patient outcomes over the last several years; however, a number of questions about this approach remain to be addressed. Through the Istituto Toscano Tumori and the Italian Association of Women Against Lung Cancer Project, we collected 411 lung adenocarcinomas from several clinical centers in Tuscany. Mutations were assessed by sequencing exons 18-21 of the epidermal growth factor receptor gene, and by restriction fragment length polymorphism analysis of codons 12 and 13 of the K-RAS gene. Epidermal growth factor receptor mutations (12.6\%) were more frequently observed in females $(p<0.0001)$, in nonsmokers $(\mathrm{p}=0.005)$, and in the presence of bronchioloalveolar features $(p=0.0004)$. K-RAS mutations $(17.9 \%)$ were more frequent in males $(\mathrm{p}=0.0007)$ and were associated with smoking habits $(\mathrm{p}=0.005)$. Epidermal growth factor receptor and K-RAS mutations were mutually exclusive $(\mathrm{p}=0.001)$. We focused on 21 female patients with advanced/metastatic lung adenocarcinoma who received gefitinib $250 \mathrm{mg} /$ day (expanded access) or erlotinib $150 \mathrm{mg} / \mathrm{die}$ as second/thirdline therapy; partial response was associated with classic epidermal growth factor receptor mutations $(\mathrm{p}=0.006)$ and with a non-smoking history $(\mathrm{p}=0.02)$. None of the female patients with partial response and/or stable disease showed K-RAS alterations. Although the data obtained in our study have yet to be analyzed and confirmed with a larger number of patients treated with tyrosine kinase inhibitors, they should provide useful information for targeted therapy, in particular for non-smoking female lung cancer patients.
\end{abstract}

Correspondence to: Professor Gabriella Fontanini, Department of Surgery, Via Roma 57, 56126 Pisa, Italy

E-mail: g.fontanini@med.unipi.it

Key words: EGFR, K-RAS, mutation, non-small cell lung cancer

\section{Introduction}

Targeting the epidermal growth factor receptor (EGFR) has played a central role in advanced non-small cell lung cancer (NSCLC) research, treatment, and patient outcomes over the last several years. Recent findings have shown that mutations in the tyrosine kinase domain of the EGFR gene are significantly associated with a high sensitivity to tyrosine kinase inhibitors (TKIs), such as gefitinib and erlotinib (1-3). Several clinicopathologic factors have been identified as being related to the frequency of EGFR mutations, including adenocarcinoma histology, female gender, non-smoking status, and East Asian ethnicity (4).

In spite of the strong association between EGFR genotype and TKI sensitivity, EGFR somatic mutations are neither sufficient nor necessary for a drug response (5). Studies have demonstrated that EGFR somatic mutations are found in only $81 \%$ of lung cancer patients who are both treated with gefitinib (or erlotinib) and experience partial responses or significant clinical improvement; furthermore, not all patients sensitive to gefitinib have EGFR mutations. These findings suggest that gender, smoking status, or interactions between these factors influence the EGFR mutational spectrum in an exon-specific manner in NSCLC cases.

Although a great deal has been learned since the initial discovery of EGFR mutations in lung cancer, a number of fundamental questions remain to be addressed. Different mutations in EGFR may confer different tumor activation profiles that lead to variations in both the natural history and clinical course of NSCLC after treatment with erlotinib or gefitinib. The clinical impact of EGFR-TKIs on patients with different mutations seems to depend on the specific EGFR mutation present (6-8). Moreover, mutations at other points of the EGFR pathway have been identified; in particular, K-RAS mutations are frequently found in lung adenocarcinomas (15-50\%) (9). Most of these mutations are observed at codon 12 (GGT) or 13 (GGC) in exon 2, and the most frequent type of mutation involves a $\mathrm{G}$ to $\mathrm{A}$ transition or $\mathrm{G}$ to $\mathrm{T}$ transversion at the second position of codon 12 . Several studies report that lung tumors with K-RAS mutations are resistant to EGFR-TKIs $(10,11)$ but so far, these findings 
have provided insufficient reason to prevent patients with K-RAS mutations from receiving EGFR-TKI therapy, as they may still derive clinical benefit from the treatment.

The lung cancer incidence recorded by the Tuscan Cancer Registry (RTT) was reported to be 2190 cases (1688 men, $77 \%$, and 502 women, 23\%) during a 1-year period (September 2006-September 2007); in women, the incidence of primary lung cancer is still increasing. The adenocarcinoma histotype accounts for $50 \%$ of the cases, with a high percentage in women. In this study, we carried out mutational profiling of 411 lung adenocarcinomas, assessing mutations in exons 18 to 21 of the EGFR gene and in codons 12 and 13 of the K-RAS gene. Moreover, we focused on 46 female patients in our series with advanced/metastatic lung adenocarcinoma, and analyzed their smoking history and clinical responsiveness to TKIs in relation to their EGFR and K-RAS mutational status.

\section{Materials and methods}

Sample collection and processing. Four hundred and eleven cytological/histological specimens of lung adenocarcinoma were consecutively collected at the Pathological Anatomy section of the Surgical Department of Pisa University from September 1, 2006 to September 1, 2007. The samples were provided by the following Pathological Anatomy Centers of Tuscany, Italy: U.O. Anatomia Patologica III AOU Pisa; U.O. Anatomia Patologica AOU Firenze; U.O. Citopatologia CSPO Firenze; Anatomia Patologica Spedali Riuniti Pistoia; U.O. Anatomia Patologica USL12 Viareggio; U.O. Anatomia Patologica USL6 Livorno; U.O. Anatomia Patologica USL1 Carrara.

Informed consent was obtained from individual patients for tissue collection and gene analyses for research purposes, in accordance with the protocol reviewed and approved by each center's Institutional Review Board.

Slides of all specimens were incubated in xylene overnight to remove the coverslip and paraffin, then washed in $100 \%$ and $70 \%$ ethanol. The cells were microdissected using a 25 -gauge needle. While viewing the tissue through the microscope, the cell population of interest was gently scraped with the microdissecting needle. The tip of the needle with the procured tissue fragments was then placed into a small PCR tube containing the appropriate buffer. The tube was shaken gently to ensure detachment of the tissue from the tip of the needle.

Patients and tumor characteristics. The pathologic features (histologic subtype, grade, and post-surgical staging) of each tumor were evaluated according to the WHO 2004 histologic criteria (12) and the International Union Against Cancer tumor-node-metastasis classification (13) in 235 out of 411 tumors. In these cases, surgical resection was performed, and the tumor samples were suitable for post-surgical evaluation. Of the 235 patients, 184 patients $(78.3 \%)$ had a lobectomy, $46(19.6 \%)$ patients had a wedge resection, and the remaining 5 patients $(2.1 \%)$ had a pneumonectomy. Classifying the 235 patients by tumor status, there were $69 \mathrm{~T} 1$ (29.3\%), $104 \mathrm{~T} 2$ (44.3\%), $26 \mathrm{~T} 3(11.1 \%)$, and $36 \mathrm{~T} 4$ (15.3\%). Thirty-two patients were classified as N1 (13.6\%), 71 as N2 (30.2\%),
Table I. Clinicopathological features and EGFR and K-RAS mutational status of patients with lung adenocarcinoma.

\begin{tabular}{lr}
\hline Clinicopathological characteristics & No. of cases $(\%)$ \\
\hline Age (years) $(\mathrm{n}=411)$ & \\
Range 37-88 & \\
Average 65.7 & \\
Gender (n=411) & $235(57.2)$ \\
Male & $176(42.8)$ \\
Female & \\
Smoking status $(\mathrm{n}=217)$ & $110(50.7)$ \\
Current & $55(25.3)$ \\
Former & $52(24.0)$ \\
Never & \\
EGFR status $(\mathrm{n}=411)$ & $359(87.4)$ \\
Wild-type & $52(12.6)$ \\
Mutated & \\
K-RAS status $(\mathrm{n}=374)$ & $307(82.1)$ \\
Wild-type & $67(17.9)$ \\
Mutated &
\end{tabular}

and 10 as $\mathrm{Nx}(4.3 \%)$, while $122(51.9 \%)$ did not show metastatic nodal involvement at the time of diagnosis. The different histologic subtypes/patterns of adenocarcinoma were documented as follows: mixed $(118 / 235,50.2 \%)$, acinar $(44 / 235,18.7 \%)$, bronchioloalveolar mucinous/non-mucinous $(14.5 \%, 3 / 235$ and $31 / 235$, respectively), papillar (16/235, $6.8 \%)$, solid $(12 / 235,5.1 \%)$, and mucinous $(11 / 235,4.7 \%)$.

Particular attention was paid to distinguishing tumors with bronchioloalveolar features $(51 / 235,21.7 \%, 34$ single pattern and 17 mixed pattern) from those without. In 176 of the 411 tumor samples ( 82 histological and 94 cytological samples) the material was insufficient (or inadequate, in the cases of biopsy and cytological samples) for performing a complete characterization according to the different subtypes of adenocarcinoma.

Regarding gender, there were 235 males (57.2\%) and 176 females $(42.8 \%)$, with age at diagnosis ranging from 37 to 88 years (mean age 65.7 years, median 66 years). Smoking habits were known for 217 of the 411 patients: there were 52 non-smokers (24\%, 14 men and 38 women), 55 former smokers $(25.3 \%, 40$ men and 15 women), and 110 current smokers $(50.7 \%, 73$ men and 37 women) (Table I).

Female patients with advanced disease. To ascertain the degree to which, in women, mutations in the EGFR tyrosine kinase domain and in the K-RAS codons 12-13 are predictive of an effective response to TKIs, we focused our attention on 46 women in our series with histologically and cytologically proven stage IV adenocarcinoma of the lung. Twenty-one patients were treated with gefitinib $250 \mathrm{mg} /$ day (expanded access) or erlotinib $150 \mathrm{mg} / \mathrm{die}$ as second/third-line therapy. Single agent gefitinib $250 \mathrm{mg} /$ day (expanded access) or erlotinib $150 \mathrm{mg} / \mathrm{die}$ (according to indication) were admi- 
Table II. Epidermal growth factor receptor (EGFR) mutation in 411 samples of lung adenocarcinoma.

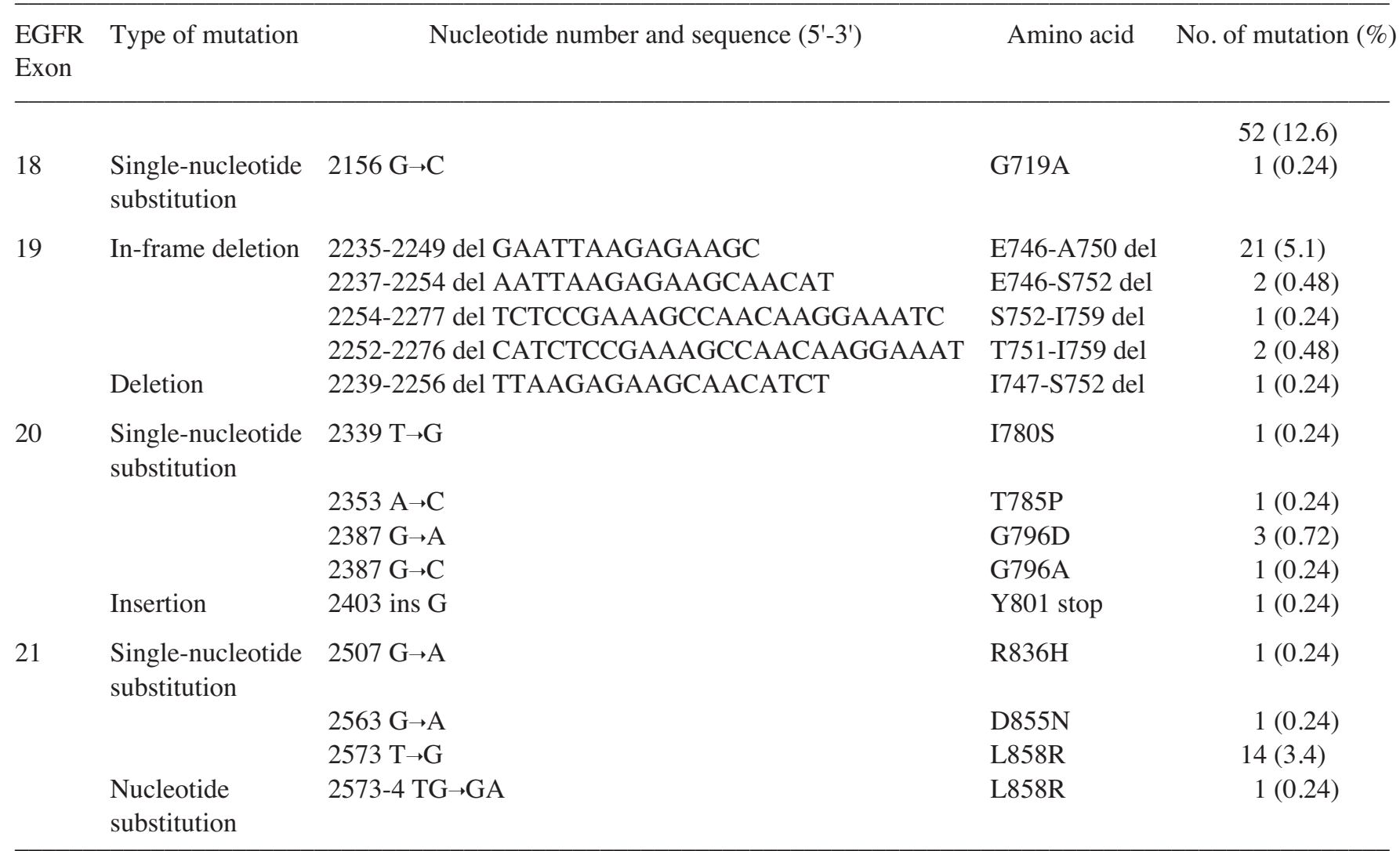

nistered orally until the onset of progression, unacceptable toxicity, or refusal. Restaging occurred every two months. Radiographic tumor responses to treatment were evaluated according to the Response Evaluation Criteria for Solid Tumors (14). Age at diagnosis ranged from 40 to 86 years (mean age 60.8 years, median 58 years). Histology demonstrated bronchioloalveolar features in 7 out of 46 samples $(15.2 \%)$. Smoking habits were known for all of them: there were 29 non-smokers (63\%), 3 former smokers $(6.5 \%)$, and 14 current smokers $(30.5 \%)$. Twenty-six women $(26 / 46$, $56.5 \%$ ) demonstrated 2 different metastatic sites, and the other 20 more than two sites; the dominant metastatic sites were in the lungs $(18 / 46,39.1 \%)$, bone $(13 / 46,28.3 \%)$, central nervous system $(8 / 46,17.4 \%)$, and liver $(7 / 46,15.2 \%)$.

DNA extraction. Genomic DNA was isolated from cytological specimens and histological tissues by a standard method. Paraffin was removed by xylene extraction, and the sample was subsequently lysed by proteinase K. DNA extraction was then performed using a spin column procedure (QIAamp Tissue kit, Qiagen).

Mutational profiling of EGFR and K-RAS. Mutational profiling of EGFR (exons 18-21) and K-RAS (codons 12 and 13) was performed as previously reported (15). Briefly, the eluted DNA was used as template in a standard $20 \mu \mathrm{l}$ PCR reaction mixture. The PCR product sizes for EGFR exons 18, 19,20 , and 21 were $207,194,247$, and 235 bp, respectively.
Because both primers had similar melting temperatures, the same PCR conditions were used to simultaneously amplify the four exons (in separate reaction tubes). The PCR conditions to amplify EGFR exons were initial denaturation at $94^{\circ} \mathrm{C}$ (7 min) followed by 35 cycles of denaturation at $94^{\circ} \mathrm{C}$ for $60 \mathrm{sec}$, annealing at $58^{\circ} \mathrm{C}$ for $60 \mathrm{sec}$, and synthesis at $72^{\circ} \mathrm{C}$ for $60 \mathrm{sec}$, followed by a final extension for $7 \mathrm{~min}$. In negative controls, the DNA template was omitted from the reaction. The amplification products were separated on $2 \%$ agarose gels and visualized by ethidium bromide staining. For the detection of mutations, PCR products were purified with the QIAquick PCR Purification Kit (Qiagen), and sequenced using a cyclic sequencing kit (ALFexpress II, Amersham Biosciences) following the manufacturer's recommendations.

For the K-RAS mutational analysis, previously extracted DNA was amplified by a mutagenic PCR assay. We used a mismatched upstream primer for codon 12 amplification and a mismatched downstream primer for codon 13 amplification, which introduced a Bst NI or a HaeIII restriction site into the wild-type allele, respectively.

Using RFLP analysis (restriction fragment length polymorphism analysis), Bst NI digestion of the wild-type codon 12 allele yields two bands of 133 and 29 bp, while the mutant remains intact (162 bp). HaeIII digestion of the wildtype codon 13 allele yields fragments of 85, 48, and $26 \mathrm{bp}$, while the mutant produces only two fragments of 85 and 74 bp (a common HaeIII site at nucleotide 85 yields an 85 bp fragment in all samples). 

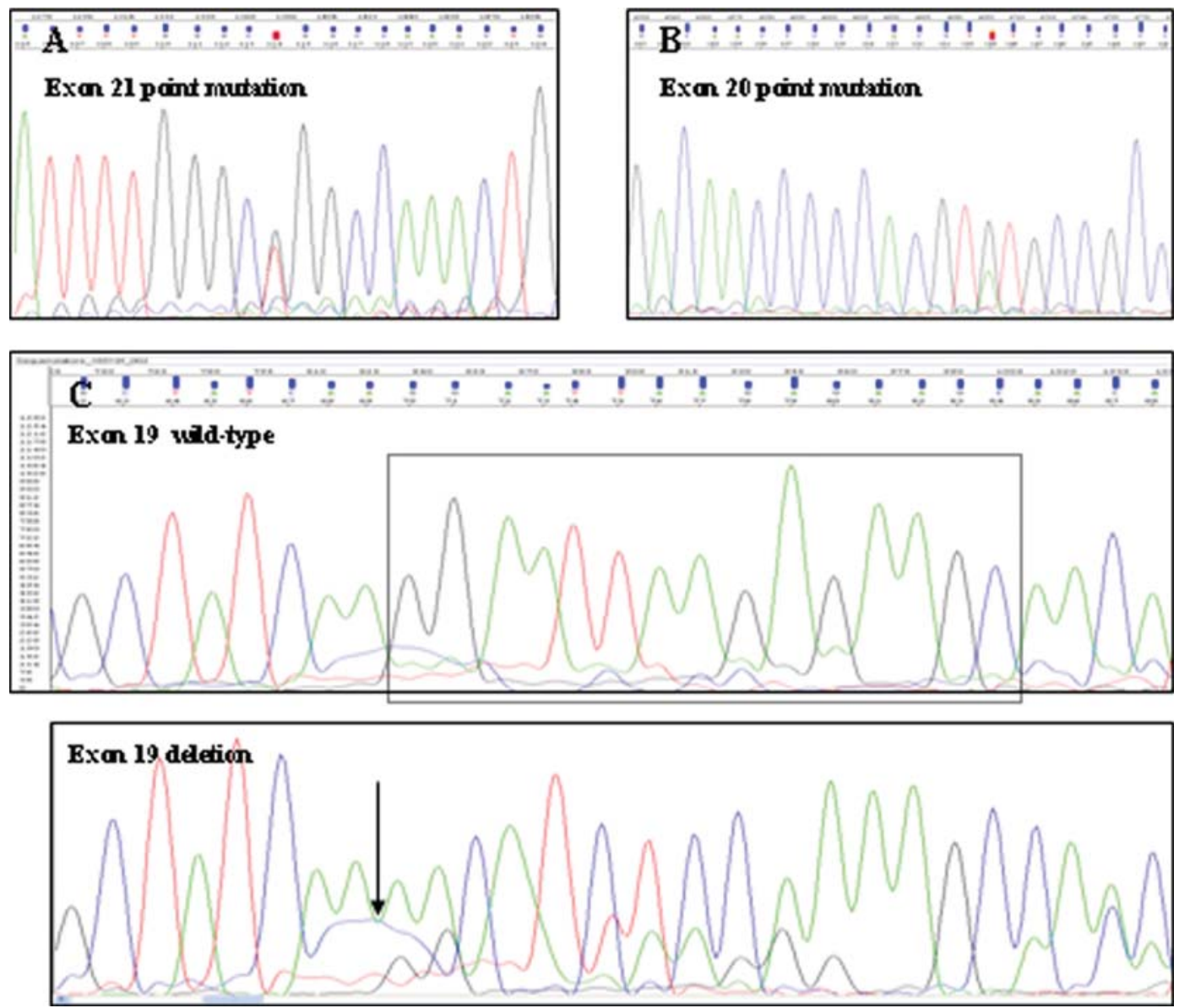

Figure 1. Representative electropherograms of mutations in the EGFR gene in lung adenocarcinomas. (A) L858R (T $\rightarrow$ G) mutation in EGFR exon 21 (B) G796D $(\mathrm{G} \rightarrow \mathrm{A})$ mutation in EGFR exon $20(\mathrm{C})$ in-frame deletion E746-A750 in EGFR exon 19 in comparison to the wild-type sequence.

Statistical analysis. All statistical analyses were carried out using Statistica software (Stat-soft). The $\chi^{2}$ test was used to analyze the associations between the different variables. The a priori level of significance was set at a p-value of $<0.05$.

\section{Results}

EGFR mutations. EGFR mutations were present in 52 patients $(12.6 \%)$ (Table I). The mutations were as follows: 1 in exon 18, 27 in exon 19, 7 in exon 20, and 17 in exon 21. Mutations of exon 19 consisted of in-frame deletions involving five amino acids from codons 746 through 750 (ELREA), and six to nine amino acids around codons 747 to 759 . Most of the mutations in exon 21 were missense substitutions resulting in a change from leucine to arginine at codon 858 (L858R). Other mutations in exons 18, 20, and 21 were single nucleotide substitutions (Table II).

One hundred and seventy-one $(171 / 411,41.6 \%)$ silent mutations occurred in exon 20: at 2316, a $\mathrm{G} \rightarrow \mathrm{A}$ transition, which did not alter the encoded amino acid of glutamine at codon 787 (Q787Q). The allele frequencies of polymorphisms at codon $787 \mathrm{CAG} / \mathrm{CAA}$ were $\mathrm{G} / \mathrm{G}(60.6 \%), \mathrm{G} / \mathrm{A}(22.7 \%)$, and A/A (16.7\%). Twelve silent mutations of $2316 \mathrm{G} \rightarrow \mathrm{A}$ were found to coexist $\left(\chi^{2}\right.$ test; $\left.\mathrm{p}=0.01\right)$ with other mutations in exons 18,19 , and 21 , and in a single case, with a mutation in
Table III. Association between EGFR mutations and clinical variables.

\begin{tabular}{lccc}
\hline & \multicolumn{2}{c}{ EGFR status } & \\
\cline { 2 - 3 } Variable & $\begin{array}{c}\text { Mutated } \\
\text { n (\%) }\end{array}$ & $\begin{array}{c}\text { Wild-type } \\
\text { n (\%) }\end{array}$ & p-value \\
\hline Gender & & & $<\mathbf{0 . 0 0 0 1}$ \\
Male & $15(28.8)$ & $220(61.3)$ & \\
Female & $37(71.2)$ & $139(38.7)$ & \\
Age (years $)$ & & & 0.33 \\
$\leq 66$ & $24(46.1)$ & $191(53.2)$ & \\
$>66$ & $28(53.9)$ & $168(46.8)$ & \\
Smoking & & & $\mathbf{0 . 0 0 5}$ \\
Current & $9(30.0)$ & $101(54.0)$ & \\
Former & $7(23.3)$ & $48(25.7)$ & \\
Never & $14(46.7)$ & $38(20.3)$ & \\
Stage & & & 0.21 \\
$<$ IIIA & $16(53.3)$ & $134(65.4)$ & \\
$\geq$ IIIA & $14(46.7)$ & $71(34.6)$ & \\
BAC features & & & $\mathbf{0 . 0 0 0 4}$ \\
Present & $14(46.7)$ & $37(18.0)$ & \\
Absent & $16(53.3)$ & $168(82.0)$ & \\
\hline
\end{tabular}



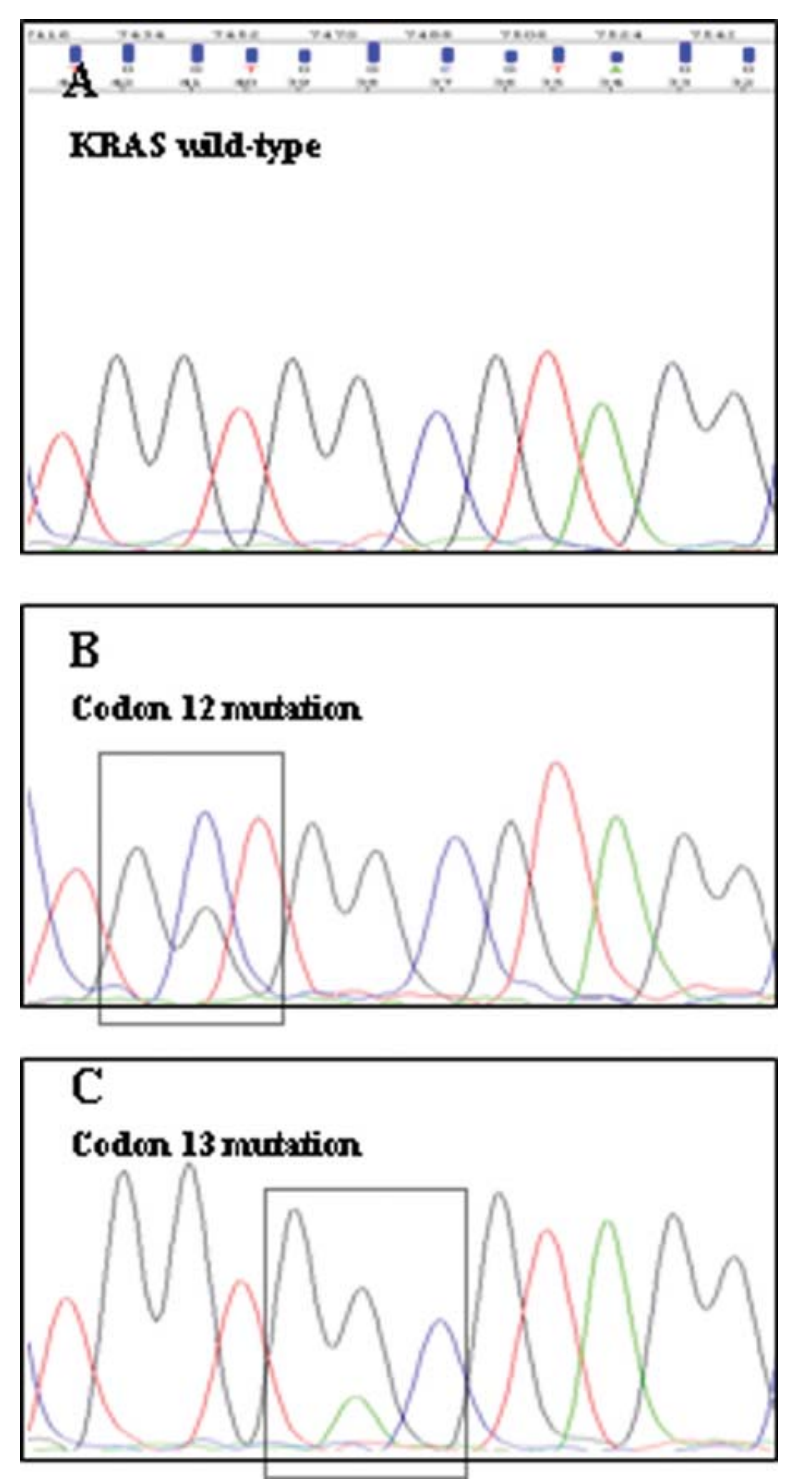

Figure 2. Representative electropherograms of mutations in the K-RAS gene in lung adenocarcinomas. (A) Wild-type sequence (B) heterozygous sample for codon 12 mutation (C) heterozygous sample for codon 13 mutation.

exon 20. Representative nucleotide sequences of the EGFR mutations are shown in Fig. 1.

$K$-RAS mutations. There was no available material for K-RAS mutational analysis in 37 cases. K-RAS mutations were detected in 67 samples $(67 / 374,17.9 \%$ ) (Table I); about $80 \%$ of the mutations (54/67) involved codon 12. Examples of sequencing of representative RFLP products for K-RAS mutational analysis are shown in Fig. 2. The occurrence of EGFR and K-RAS mutations was strictly mutually exclusive $\left(\chi^{2}\right.$ test; $\left.\mathrm{p}=0.001\right)$.

Association between EGFR mutations and clinical variables. We categorized the clinical variables for analysis as follows: age, younger ( $\leq 66$ years old) vs. older ( $>66$ years old); TNM stage, early (< stage IIIA) vs. advanced stage ( $\geq$ stage IIIA).

Clinical variables, such as gender, age, smoking habits, TNM stage, and presence of bronchioloalveolar features,
Table IV. Association between K-RAS mutations and clinical variables.

\begin{tabular}{|c|c|c|c|}
\hline \multirow[b]{2}{*}{ Variable } & \multicolumn{2}{|c|}{ K-RAS status } & \multirow[b]{2}{*}{ p-value } \\
\hline & $\begin{array}{c}\text { Mutated } \\
\text { n (\%) }\end{array}$ & $\begin{array}{c}\text { Wild-type } \\
\text { n (\%) }\end{array}$ & \\
\hline Gender & & & 0.0007 \\
\hline Male & $51(76.1)$ & $164(53.4)$ & \\
\hline Female & $16(23.9)$ & 143 (46.6) & \\
\hline Age (years) & & & 0.94 \\
\hline$\leq 66$ & $35(52.2)$ & $159(51.8)$ & \\
\hline$>66$ & $32(47.8)$ & $148(48.2)$ & \\
\hline Smoking & & & 0.005 \\
\hline Current & $19(46.3)$ & $81(51.6)$ & \\
\hline Former & $18(43.9)$ & $34(21.7)$ & \\
\hline Never & $4(9.8)$ & $42(26.7)$ & \\
\hline Stage & & & 0.67 \\
\hline$<$ IIIA & $26(60.5)$ & 117 (63.9) & \\
\hline$\geq$ IIIA & $17(39.5)$ & $66(36.1)$ & \\
\hline BAC features & & & 0.53 \\
\hline Present & 8 (18.6) & $42(23.0)$ & \\
\hline Absent & $35(81.4)$ & $141(77.0)$ & \\
\hline
\end{tabular}

were analyzed in association with EGFR mutational status (Table III). No association with age and clinical stage was found, while EGFR mutations were more frequently observed in females $(\mathrm{p}<0.0001)$, in non-smokers $(\mathrm{p}=0.005)$, and in the presence of bronchioloalveolar features $(\mathrm{p}=0.0004)$.

Association between K-RAS mutations and clinical variables. K-RAS mutational status was analyzed in association with clinical variables (Table IV); we observed that K-RAS mutations were more frequent in males $(p=0.0007)$ and were associated with smoking habits (current and former) $(\mathrm{p}=0.005)$. No statistically significant association was found with the other clinical characteristics.

EGFR and K-RAS mutations in female patients with advanced disease. EGFR sequencing analysis revealed that mutations were present in 12 out of 46 (26.1\%) female patients with advanced disease. There were 7 mutations in exon 19, 2 in exon 20, and 3 in exon 21 (Table V). Fourteen $(14 / 46,30.43 \%)$ silent mutations $(2316 \mathrm{G} \rightarrow \mathrm{A}$ transition $)$ occurred in exon 20 without altering the encoded amino acid of glutamine at codon 787 (Q787Q). For the K-RAS gene, mutations were identified in $15.8 \%$ ( 6 out of 46 ) of patients: four cases involved codon 12 and two involved codon 13 .

Twenty-one female patients $(21 / 46,45.6 \%)$ among those with advanced disease received TKIs, gefitinib $250 \mathrm{mg} /$ day (expanded access) or erlotinib $150 \mathrm{mg} / \mathrm{die}$, as second/thirdline therapy; 9/21 (42.9\%) showed progressive disease, $4 / 21$ (19\%) showed stable disease, and 8/21 (38.1\%) showed a partial response. The median duration of response was 8 months (range 2-24 months). Seven out of 21 (33.3\%) female 
Table V. EGFR mutations in female patients with advanced disease.

\begin{tabular}{|c|c|c|c|c|c|}
\hline Patient no. & EGFR exon & Nucleotide number and sequence $\left(5^{\prime}-3^{\prime}\right)$ & Amino acid & Smoking & Response \\
\hline 1 & 19 & 2235-2249 del GAATTAAGAGAAGC & E746-A750 del & No & PR \\
\hline 2 & 19 & 2235-2249 del GAATTAAGAGAAGC & E746-A750 del & No & PR \\
\hline 3 & 19 & 2237-2254 del AATTAAGAGAAGCAACAT & E746-S752 del & No & $\mathrm{NE}$ \\
\hline 4 & 19 & 2254-2277 del TCTCCGAAAGCCAACAAGGAAATC & S752-I759 del & No & PR \\
\hline 5 & 19 & 2235-2249 del GAATTAAGAGAAGC & E746-A750 del & No & $\mathrm{NE}$ \\
\hline 6 & 19 & 2235-2249 del GAATTAAGAGAAGC & E746-A750 del & No & PR \\
\hline 7 & 19 & 2235-2249 del GAATTAAGAGAAGC & E746-A750 del & No & $\mathrm{NE}$ \\
\hline 8 & 20 & $2387 \mathrm{G} \rightarrow \mathrm{A}$ & G796D & Yes & $\mathrm{NE}$ \\
\hline 9 & 20 & $2387 \mathrm{G} \rightarrow \mathrm{C}$ & G796A & Yes & NE \\
\hline 10 & 21 & $2507 \mathrm{G} \rightarrow \mathrm{A}$ & $\mathrm{R} 836 \mathrm{H}$ & Yes & PD \\
\hline 11 & 21 & $2573 \mathrm{~T} \rightarrow \mathrm{G}$ & L858R & No & PR \\
\hline 12 & 21 & $2573 \mathrm{~T} \rightarrow \mathrm{G}$ & L858R & No & PR \\
\hline
\end{tabular}

PR, partial response; NE, not evaluated; PD, progressive disease.

Table VI. Associations between EGFR and K-RAS mutations, smoking status and tumor response in TKIs-treated patients.

\begin{tabular}{lccc}
\hline & $\begin{array}{c}\text { Partial } \\
\text { response } \\
\mathrm{n}=8\end{array}$ & $\begin{array}{c}\text { Stable } \\
\text { disease } \\
\mathrm{n}=4\end{array}$ & $\begin{array}{c}\text { Progressive } \\
\text { disease } \\
\mathrm{n}=9\end{array}$ \\
\hline EGFR & 2 & 4 & 8 \\
Wild-type & 6 & 0 & 1 \\
Mutated & & & \\
K-RAS & 8 & 4 & 7 \\
Wild-type & 0 & 0 & 2 \\
Mutated & & & \\
Smoking history & 8 & 1 & 5 \\
No & 0 & 3 & 4 \\
Yes & & & \\
\hline
\end{tabular}

patients treated with TKIs showed EGFR mutations. In a patient with progressive disease, there was a mutation at codon 836 in exon 21 which has never been previously reported in the literature; six classic EGFR mutations were observed in women with a partial response, while none of the 4 patients with stable disease after TKIs treatment showed EGFR alterations $(p=0.006)$. For the K-RAS gene in TKIstreated patients, mutations were identified in 2 out of $21(9.5 \%)$ cases. None of the female patients with partial response and/or stable disease showed K-RAS mutations. Moreover, partial response was associated with a non-smoking history (8/8), while 4/9 patients with progressive disease, and 3/4 with stable disease were current smokers $(\mathrm{p}=0.02)$ (Table VI).

The group of twenty-five female patients with advanced disease who were not treated with TKIs $(25 / 46,54.4 \%)$ showed five EGFR $(5 / 25,20 \%)$ and four K-RAS $(4 / 25,16 \%)$ mutations.

\section{Discussion}

Although a great number of studies have been performed on EGFR and K-RAS status in several human cancer models, no prospective study has been conducted on a homogeneous and large series of patients. Within the Istituto Toscano Tumori and the Italian Association of Women Against Lung Cancer $\left(\mathrm{AIDA}^{\mathrm{CP}}\right)$, we saw the need to evaluate EGFR and K-RAS status in a wide population of patients diagnosed with lung carcinoma. Based on the high incidence of lung carcinoma in Tuscany (particularly in certain areas) and on the fact that EGFR and K-RAS mutations seem to have a major impact on the development and progression of certain subtypes of adenocarcinoma, we designed our study with the aim of determining the actual incidence of EGFR mutations in a wide group of lung adenocarcinomas, prospectively collected from different areas of Tuscany. In our series, EGFR mutations were more frequently found in cases with bronchioloalveolar features, in agreement with results recently published by Kim et al (16), suggesting a possible correlation between pathological characteristics and molecular changes to EGFR. We found that the frequency of EGFR mutations (12.6\%) is in the range of $3-13 \%$, as reported in the literature (1-3), is higher in women $(37 / 176,21 \%)$ than men $(15 / 235,6.4 \%)$, and is more prevalent in non-smokers $(14 / 52,26.9 \%)$ than in current $(9 / 110,8.2 \%)$ or former smokers $(7 / 55,12.7 \%)$. Data from other studies in Europe corroborate our results, showing a similar incidence of EGFR mutations in subgroups of patients with lung adenocarcinoma. In contrast, our observations differed significantly from those in several Asian studies, due to the greater prevalence of EGFR mutations in Asian populations (35-63\% vs. 6-12.6\%) (Table VII) (16-20). The implication of these findings is that ethnicity may determine different genetic backgrounds in common tumors, thereby influencing clinical outcome and response to therapy.

EGFR mutations were the first molecular aberrations found in lung cancer, and were found to be more frequent 
Table VII. Epidermal growth factor receptor (EGFR) and K-RAS gene mutations in patients with lung adenocarcinoma.

EGFR mutations in subgroups of patients with adenocarcinoma

\begin{tabular}{|c|c|c|c|c|c|c|c|c|}
\hline \multirow[b]{2}{*}{ Author } & \multirow[b]{2}{*}{ Ethnicity } & \multirow[b]{2}{*}{$\mathrm{N}$} & \multirow[b]{2}{*}{ K-RAS mutation (\%) } & \multirow[b]{2}{*}{ EGFR mutation (\%) } & \multicolumn{2}{|c|}{ Sex } & \multicolumn{2}{|c|}{ Smoking history } \\
\hline & & & & & Male (\%) & Female $(\%)$ & Yes $(\%)$ & $\mathrm{No}(\%)$ \\
\hline Kim et al (16) & Asian & 71 & 7 & 35 & 24 & 45 & 23 & 45 \\
\hline Haneda et al (17) & Asian & 95 & ND & 39 & 33 & 45 & 30 & 45 \\
\hline Sakuma et al (18) & Asian & 118 & 8.5 & 63 & 39 & 81 & 44 & 78 \\
\hline Marchetti et al (19) & Italian & 375 & 28.8 & 10 & 6 & 30 & 7 & 25 \\
\hline Savic et al (20) & Swiss & 49 & ND & 6 & 3.6 & 16 & ND & ND \\
\hline Present study & Italian & 411 & 17.9 & 12.6 & 6 & 21 & 8 & 27 \\
\hline
\end{tabular}

$\mathrm{ND}$, non determined.

among non-smoking patients than among patients who smoked (21). However, this does not suggest that smoking has a preventive effect on EGFR mutations; rather, it is reasonable to assume that EGFR mutations are caused by carcinogens other than those contained in tobacco smoke. The apparent negative correlation with smoking likely results from diluting the number of tumors with EGFR mutations amidst a higher number of tumors with wild-type EGFR associated with higher levels of smoking, as suggested in a recent case-control study by Matsuo et al (22).

The influence of gender has also been an issue of interest, with the suggestion that female gender is associated with EGFR mutations (23-25). In contrast, Huang et al (26) reported no strong association between female gender or smoking status and the presence of a mutation in a group of adenocarcinomas. It is not clear whether female gender is directly associated with EGFR mutation per se, or whether this association results from erroneous analyses confounded by the higher prevalence of adenocarcinoma among women. The results in our study support the dominant finding that gender, smoking, and the interaction of these two factors differentially affect the site of somatically acquired EGFR mutations. However, the reasons for the impact of gender difference on the mutational spectrum are unclear, and thus warrant further investigation into the basis of this association, including the possible involvement of sex hormones.

The clinical effect of EGFR-TKIs on patients with various mutations seems to depend on the specific EGFR mutant present. Mitsudomi et al (27) first reported that the response rate of gefitinib was higher in patients with deletional EGFR mutations than in those with other types of mutations, which were predominantly L858R; recently, Pallis et al (28) demonstrated that classic (but not 'other') mutation variants of the EGFR gene are associated with response to TKIs.

Greulich et al (6) showed that one of the insertion mutations (D770insNPG) in exon 20 is associated with in vitro resistance to erlotinib. In that study, G719S of exon
18 showed intermediate sensitivity in vitro, lower than exon 19 or exon 21 mutant cells. In a transgenic mouse model, L858R mutants were associated with more aggressive adenocarcinomas compared to exon 19 deletion mutants (delL747S752) (29). Mulloy et al (30) showed that Del747-753 kinase had a higher autophosphorylation rate and higher sensitivity to erlotinib than the L858R kinase. All these data reflect the differences in clinical response rates between exon 19 deletional mutations and L858R. Our study on 21 female patients receiving TKIs also supported the postulation that the type of mutation was correlated with tumor response, with $75 \%$ of the patients showing partial response having classic EGFR mutations, none of the patients with stable disease displaying EGFR mutations, and only one non-classic EGFR mutation among patients with progressive disease. Moreover, our observations correlate extremely well with the clinical response data, with EGFR mutation carriers being sensitive to tyrosine kinase inhibition and having a higher frequency of non-smokers (31).

Other factors also affect tumor response to TKIs; an activating mutation of the K-RAS gene was one of the earliest discoveries of genetic alterations in lung cancer. Huncharek et al (32) analyzed a series of studies and concluded that there is an approximately $25 \%$ incidence ratio of K-RAS mutations in Caucasian populations; our percentage (67 out of 374 patients, $17.9 \%$ ) is within this range (Table VII) $(16,18,19)$.

The incidence of simultaneous K-RAS mutations and EGFR mutations has been investigated by several groups, following the realization that there is a correlation between K-RAS mutations and smoking status (33) and that certain K-RAS mutations correlate with resistance to TK inhibition of EGFR signaling (10). It has been shown that EGFR and K-RAS mutations are mutually exclusive. We have seen a similar result in our patient population, and have observed that males and smokers have a higher incidence of K-RAS mutations, while no K-RAS mutations were found in female patients with stable and/or regressive disease. 
Moreover, we and others have reported the existence of silent polymorphisms in the EGFR exons, as well as their co-occurrence with other mutations $(31,34)$. Additional information, either retrospective and/or prospective, is required to determine the significance of not only the classic exonic EGFR mutations, but also the intronic and silent mutations.

\section{Acknowledgments}

This research was supported by the Istituto Toscana Tumori (ITT), and by AIDA ${ }^{\mathrm{CP}}$ (Italian Association of Women Against Lung Cancer). We thank Professor Lucio Luzzatto for indispensable scientific and organizational support. We also thank Dr Valentina Donati for reviewing histologic subtypes. We thank the U.O. Anatomia Patologica AOU Firenze; U.O. Citopatologia CSPO Firenze; Anatomia Patologica Spedali Riuniti Pistoia; U.O. Anatomia Patologica USL12 Viareggio; U.O Anatomia Patologica USL6 Livorno; and U.O. Anatomia Patologica USL1 Carrara, Italy, for providing tumor samples.

\section{References}

1. Lynch TJ, Bell DW, Sordella R, Gurubhagavatula S, Okimoto RA, Brannigan BW, Harris PL, Haserlat SM, Supko JG, Haluska FG, Louis DN, Christiani DC, Settleman J and Haber DA: Activating mutations in the epidermal growth factor receptor underlying responsiveness of non-small-cell lung cancer to gefitinib. N Engl J Med 350: 2129-2139, 2004.

2. Paez JG, Janne PA, Lee JC, Tracy S, Greulich H, Gabriel S, Herman P, Kaye FJ, Lindeman N, Boggon TJ, Naoki K, Sasaki H, Fujii Y, Eck MJ, Sellers WR, Johnson BE and Meyerson M: EGFR mutations in lung cancer: correlation with clinical response to gefitinib therapy. Science 304: 1497-1500, 2004.

3. Pao W, Miller V, Zakowski M, Doherty J, Politi K, Sarkaria I, Singh B, Heelan R, Rusch V, Fulton L, Mardis E, Kupfer D, Wilson R, Kris M and Varmus H: EGF receptor gene mutations are common in lung cancers from 'never smokers' and are associated with sensitivity of tumors to gefitinib and erlotinib. Proc Natl Acad Sci USA 101: 13306-13311, 2004.

4. Shigematsu H, Lin L, Takahashi T, Nomura M, Suzuki M, Wistuba II, Fong KM, Lee H, Toyooka S, Shimizu N, Fujisawa T, Feng Z, Roth JA, Herz J, Minna JD and Gazdar AF: Clinical and biological features associated with epidermal growth factor receptor gene mutations in lung cancers. J Natl Cancer Inst 97: 339-346, 2005

5. Arteaga CL: Selecting the right patient for tumor therapy. Nat Med 10: 577-578, 2004.

6. Greulich H, Chen TH, Feng W, Jänne PA, Alvarez JV Zappaterra M, Bulmer SE, Frank DA, Hahn WC, Sellers WR and Meyerson M: Oncogenic transformation by inhibitor-sensitive and -resistant EGFR mutants. PLoS Med 2: e313, 2005.

7. Jackman DM, Yeap BY, Sequist LV, Lindeman N, Holmes AJ, Joshi VA, Bell DW, Huberman MS, Halmos B, Rabin MS, Haber DA, Lynch TJ, Meyerson M, Johnson BE and Jänne PA: Exon 19 deletion mutations of epidermal growth factor receptor are associated with prolonged survival in non-small cell lung cancer patients treated with gefitinib or erlotinib. Clin Cancer Res 12: 3908-3914, 2006.

8. Riely GJ, Pao W, Pham D, Li AR, Rizvi N, Venkatraman ES, Zakowski MF, Kris MG, Ladanyi M and Miller VA: Clinical course of patients with non-small cell lung cancer and epidermal growth factor receptor exon 19 and exon 21 mutations treated with gefitinib or erlotinib. Clin Cancer Res 12: 839-844, 2006.

9. Mascaux C, Iannino N, Martin B, Paesmans M, Berghmans T, Dusart M, Haller A, Lothaire P, Meert AP, Noel S, Lafitte JJ and Sculier JP: The role of RAS oncogene in survival of patients with lung cancer: a systematic review of the literature with meta-analysis. Br J Cancer 92: 131-139, 2005.

10. Pao W, Wang TY, Riely GJ, Miller VA, Pan Q, Ladanyi M, Zakowski MF, Heelan RT, Kris MG and Varmus HE: KRAS mutations and primary resistance of lung adenocarcinomas to gefitinib or erlotinib. PLoS Med 2: e17, 2005.
11. Endoh H, Yatabe Y, Kosaka T, Kuwano H and Mitsudomi T: PTEN and PIK3A expression is associated with prolonged survival after gefitinib treatment in EGFR-mutated lung cancer patients. J Thorac Oncol 1: 629-634, 2006.

12. Travis WD, Brambilla E, Muller-Hermelink HK and Harris CC: World Health Organization classification of tumours. Pathology and genetics of tumours of the lung, pleura, thymus and heart. IARC Press, Lyon, 2004.

13. Sobin LH and Wittekind C: TNM classification of malignant tumours. 6th edition. Hoboken NJ (ed). John Wiley \& Sons, 2002.

14. Therasse P, Arbuck SG, Eisenhauer EA, Wanders J, Kaplan RS, Rubinstein L, Verweij J, Van Glabbeke M, van Oosterom AT, Christian MC and Gwyther SG: New guidelines to evaluate the response to treatment in solid tumors. European Organization for Research and Treatment of Cancer, National Cancer Institute of the United States, National Cancer Institute of Canada. J Natl Cancer Inst 92: 205-216, 2000

15. Boldrini L, Gisfredi S, Ursino S, Camacci T, Baldini E, Melfi $\mathrm{F}$ and Fontanini G: Mutational analysis in cytological specimens of advanced lung adenocarcinoma: a sensitive method for mole-cular diagnosis. J Thorac Oncol 2: 10861090,2007

16. Kim YT, Kim TY, Lee DS, Park SJ, Park JY, Seo SJ, Choi HS, Kang HJ, Hahn S, Kang CH, Sung SW and Kim JH: Molecular changes of epidermal growth factor receptor (EGFR) and KRAS and their impact on the clinical outcomes in surgically resected adenocarcinoma of the lung. Lung Cancer 59: 111-118, 2008.

17. Haneda H, Sasaki H, Shimizu S, Endo K, Suzuki E, Yukiue H, Kobayashi Y, Yano M and Fujii Y: Epidermal growth factor receptor gene mutation defines distinct subsets among small adenocarcinomas of the lung. Lung Cancer 52: 47-52, 2006.

18. Sakuma Y, Matsukuma S, Yoshihara M, Nakamura Y, Noda K, Nakayama H, Kameda Y, Tsuchiya E and Miyagi Y: Distinctive evaluation of non-mucinous and mucinous subtypes of bronchioloalveolar carcinomas in EGFR and K-ras genemutation analyses for Japanese lung adenocarcinomas: confirmation of the correlations with histologic subtypes and gene mutations. Am J Clin Pathol 128: 100-108, 2007.

19. Marchetti A, Martella C, Felicioni L, Barassi F, Salvatore S, Chella A, Camplese PP, Iarussi T, Mucilli F, Mezzetti A, Cuccurullo F, Sacco R and Buttitta F: EGFR mutations in nonsmall-cell lung cancer: analysis of a large series of cases and development of a rapid and sensitive method for diagnostic screening with potential implications on pharmacologic treatment. J Clin Oncol 23: 857-865, 2005.

20. Savic S, Tapia C, Grilli B, Rufle A, Bihl MP, De Vito Barascud A, Herzog M, Terracciano L, Baty F and Bubendorf L: Comprehensive epidermal growth factor receptor gene analysis from cytological specimens of non-small-cell lung cancers. Br J Cancer 98: 154-160, 2008.

21. Kosaka T, Yatabe Y, Endoh H, Kuwano H, Takahashi T and Mitsudomi T: Mutations of the epidermal growth factor receptor gene in lung cancer: biological and clinical implications. Cancer Res 64: 8919-8923, 2004.

22. Matsuo K, Ito H, Yatabe Y, Hiraki A, Hirose K, Wakai K, Kosaka T, Suzuki T, Tajima K and Mitsudomi T: Risk factors differ for non-small-cell lung cancers with and without EGFR mutation: assessment of smoking and sex by a case-control study in Japanese. Cancer Sci 98: 96-101, 2007.

23. Mitsudomi T, Kosaka T and Yatabe Y: Biological and clinical implications of EGFR mutations in lung cancer. Int J Clin Oncol 11: 190-198, 2006.

24. Toyooka S, Matsuo K, Shigematsu H, Kosaka T, Tokumo M, Yatabe Y, Ichihara S, Inukai M, Suehisa H, Soh J, Kiura K, Fong KM, Lee H, Wistuba II, Gazdar AF, Mitsudomi T and Date H: The impact of sex and smoking status on the mutational spectrum of epidermal growth factor receptor gene in nonsmall cell lung cancer. Clin Cancer Res 13: 5763-5768, 2007.

25. Mitsudomi T and Yatabe Y: Mutations of the epidermal growth factor receptor gene and related genes as determinants of epidermal growth factor receptor tyrosine kinase inhibitors sensitivity in lung cancer. Cancer Sci 98: 1817-1824, 2007.

26. Huang SF, Liu HP, Li LH, Ku YC, Fu YN, Tsai HY, Chen YT, Lin YF, Chang WC, Kuo HP, Wu YC, Chen YR and Tsai SF: High frequency of epidermal growth factor receptor mutations with complex patterns in non-small cell lung cancers related to gefitinib responsiveness in Taiwan. Clin Cancer Res 10: 8195-8203, 2004. 
27. Mitsudomi T, Kosaka T, Endoh H, Horio Y, Hida T, Mori S, Hatooka S, Shinoda M, Takahashi T and Yatabe Y: Mutations of the epidermal growth factor receptor gene predict prolonged survival after gefitinib treatment in patients with non-small-cell lung cancer with postoperative recurrence. J Clin Oncol 23: 2513-2520, 2005

28. Pallis AG, Voutsina A, Kalikaki A, Souglakos J, Briasoulis E, Murray S, Koutsopoulos A, Tripaki M, Stathopoulos E, Mavroudis D and Georgoulias V: 'Classical' but not 'other' mutations of EGFR kinase domain are associated with clinical outcome in gefitinib treated patients with non-small cell lung cancer. Br J Cancer 97: 1560-1566, 2007.

29. Politi K, Zakowski MF, Fan PD, Schonfeld EA, Pao W and Varmus HE: Lung adenocarcinomas induced in mice by mutant EGF receptors found in human lung cancers respond to a tyrosine kinase inhibitor or to down-regulation of the receptors. Genes Dev 20: 1496-1510, 2006.

30. Mulloy R, Ferrand A, Kim Y, Sordella R, Bell DW, Haber DA, Anderson KS and Settleman J: Epidermal growth factor receptor mutants from human lung cancers exhibit enhanced catalytic activity and increased sensitivity to gefitinib. Cancer Res 67: 2325-2330, 2007.
31. Tamura K and Fukuoka M: Gefitinib in non-small cell lung cancer. Exp Opin Pharmacother 6: 985-993, 2005.

32. Huncharek M, Muscat J and Geschwind JF: K-ras oncogene mutation as a prognostic marker in non-small cell lung cancer: a combined analysis of 881 cases. Carcinogenesis 20: 1507-1510, 1999.

33. Nelson HH, Christiani DC, Mark EJ, Wiencke JK, Wain JC and Kelsey KT: Implications and prognostic value of K-ras mutations for early-stage lung cancer in women. J Natl Cancer Inst 91: 2032-2038, 1999.

34. Murray S, Timotheadou E, Linardou H, Linardou H, Vrettou AV, Kostopoulos I, Skrickova J, Papakostantinou C, Christodoulou C, Pectasides D, Samantas E, Papakostas P, Skarlos DV, Kosmidis P and Fountzilas G: Mutations of the epidermal growth factor receptor tyrosine kinase domain and associations with clinicopathological features in non-small cell lung cancer patients. Lung Cancer 52: 225-233, 2006. 